\title{
Modeling Sexual Differences of Body Size Variation in Ground Beetles in Geographical Gradients: A Case Study of Pterostichus melanarius (Illiger, 1798) (Coleoptera, Carabidae)
}

\author{
Sergey Luzyanin ${ }^{1}$ D, Anatoly Saveliev ${ }^{2} \mathbb{D}$, Nadezhda Ukhova ${ }^{3} \mathbb{D}$, Iraida Vorobyova ${ }^{4}$, Igor Solodovnikov ${ }^{5}$, \\ Anatoliy Anciferov ${ }^{6}$, Rifgat Shagidullin ${ }^{7}$, Teodora Teofilova ${ }^{8}$ (D), Sargylana Nogovitsyna ${ }^{9}$ (D), \\ Viktor Brygadyrenko ${ }^{10}\left(\mathbb{D}\right.$, Viktor Alexanov ${ }^{11}$ and Raisa Sukhodolskaya ${ }^{7, *(D)}$
}

check for updates

Citation: Luzyanin, S.; Saveliev, A.; Ukhova, N.; Vorobyova, I.; Solodovnikov, I.; Anciferov, A. Shagidullin, R.; Teofilova, T.; Nogovitsyna, S.; Brygadyrenko, V.; et al. Modeling Sexual Differences of Body Size Variation in Ground Beetles in Geographical Gradients: A Case Study of Pterostichus melanarius (Illiger, 1798) (Coleoptera, Carabidae). Life 2022, 12, 112. https://doi.org/ 10.3390/life12010112

Academic Editors: Anita Giglio and Federica Talarico

Received: 25 December 2021

Accepted: 11 January 2022

Published: 13 January 2022

Publisher's Note: MDPI stays neutral with regard to jurisdictional claims in published maps and institutional affiliations.

Copyright: (C) 2022 by the authors Licensee MDPI, Basel, Switzerland. This article is an open access article distributed under the terms and conditions of the Creative Commons Attribution (CC BY) license (https:// creativecommons.org/licenses/by/ $4.0 /)$
1 Department of Ecology and Environmental Science, Kemerovo State University, 650000 Kemerovo, Russia; sl_luzyanin@mail.ru

2 Institute of Ecology and Environmental Science, Kazan (Volga Region) Federal University, 420000 Kazan, Russia; anatoly.saveliev.aka.saa@gmail.com

3 Visim Nature Reserve, 624140 Kirovograd, Russia; ukh08@yandex.ru

4 Department of Biology, Mariy State University, 424000 Yoshkar-Ola, Russia; vigir@mail.ru

5 Department of Zoology and Botany, Vitebsk State University Named after P. M. Masherov, 210038 Vitebsk, Belarus; iasolodov@mail.ru

6 Kostroma Museum-Reserve, 156000 Kostroma, Russia; ancifer.ost@yandex.ru

7 Institute of Ecology and Mineral Resource Management, Academy of Sciences of Tatarstan Republic, Tatarstan, 420000 Kazan, Russia; Shagidullin_@mail.ru

8 Institute of Biodiversity and Ecosystem Research, Bulgarian Academy of Sciences, 1000 Sofia, Bulgaria; oberon_zoo@abv.bg

9 Institute for Biological Problems of Cryolithozone Siberian Branch Russian Academy of Sciences, 677980 Yakutsk, Russia; sarnogov@mail.ru

10 Department of Zoology and Ecology, Dnipro State Agrarian and Economic University, 49600 Dnipro, Ukraine; brigad@ua.fm

11 State Budgetary Institution of Kaluga Region "Parks Directorate", 248000 Kaluga, Russia; victor_alex@list.ru

* Correspondence: sukhodolskayaraisa@gmail.com; Tel.: +7-9503152619

Abstract: The aim of this study was to test the steepness of body size variation in males and females in the widespread ground beetle Pterostichus melanarius in geographical gradients. Beetles were sampled in 15 regions of Europe and Asia, and sampling territories differed $17^{\circ}$ in latitude and $121^{\circ}$ in longitude. We measured six linear traits in every captured beetle and formed a data set that included 2154 individuals. Body size variation in all traits in general was sawtooth, both in latitude and in longitude gradients. Regression analysis showed slight trends: in the latitude gradient, elytra parameters increased, pronotum length did not change but the width increased, and head parameters decreased. In the longitude gradient, the changes were as follows: elytra length increased, but its width did not change; pronotum length did not change, but its width increased; the head parameters decreased. Thus, we observed the elytra length increase and the head parameters decrease northwards and eastwards. We compared female and male regression curves (trait size on latitude/longitude): p-levels were significant only in four cases out of 12 . Thus, we conclude that, in general, there is no evidence for the steepness in trait variation in males compared with females.

Keywords: body size variation; ground beetles; sexual size dimorphism; geographical gradients; regression analysis

\section{Introduction}

A fundamental problem for biologists is to discover the processes driving intra- and interspecific variation in phenotypic traits [1]. Body size is an essential trait to study, because size variation directly affects fitness, physiology, and most life-history traits [2,3]. It is one of the key life-history traits in ectotherms [4,5], because it is considered a proxy for 
fecundity, body condition, and survival [6-8]. In general, larger individuals show higher fecundity and lower mortality rates $[9,10]$. Furthermore, species with wide distributional ranges show clines in body size. These may be the result of "ecogeographical rules" that discuss spatial patterns of phenotypic variation in terms of environmental variation [11,12].

Ground beetles are an interesting group in which to test ecogeographical rules because some species are widely distributed in the world and their biology and ecology are well known. In addition, they are the recognized bioindicators and respond to environmental fluctuations. Broad-scale patterns of body size variation in carabids are described poorly and have been studied in a very narrow spectrum of species [13].

Bergmann's rule is a common ecogeographical pattern. It was formulated initially for homeothermic vertebrates and predicts their body size increase in high latitudes, as larger individuals have a smaller surface area to volume ratio [14]. However, in poikilotherms, the rule cannot be implemented: in insects, $30 \%$ of 63 datasets reported converse Bergmann clines (body size decreases with latitude), and $41 \%$ were not consistent with either pattern [15].

Within Carabidae (Coleoptera), Bergmann's rule has been previously investigated only for a few species, distributed predominantly in Russia $[16,17]$. Their body size variation was genus-biased: for Carabus Linnaeus, 1758 species decreased in size with latitude gradient, while for Pterostichus Bonelli, 1810 species had body size variation that was sawtooth, and Poecilus cupreus (Linnaeus, 1758) did not change at all. Several mechanisms can drive intraspecific variation in body size for ectotherms. The first is the temperature-size rule, which postulates larger body sizes at higher latitudes, because at lower ones, with higher temperatures, insects reach maturity faster and at a smaller size [18]. This mechanism is undoubtedly relevant to small bodied insects. However, there were a lot of exceptions in investigating body size variation when rearing temperatures differed, and this rule was confirmed in a limited number of species $[19,20]$. Ecological variation can also lead to broad ecogeographical patterns in body size, unconnected to temperature per se.

Latitude covaries with other ecological factors, including primary productivity, predation, competition, food abundance, desiccation resistance, and starvation resistance, which may be alternative drivers of biogeographical patterns [21-25]. For example, the resistance hypothesis proposes that larger organisms are more likely to resist the detrimental effects of starvation or desiccation, and therefore predicts that body size should increase with latitude and altitude $[3,26]$. Similarly, seasonality can favor converse Bergmann's clines or a non-linear relationship between body size and latitude, as the limited time for foraging and growth at higher latitudes could potentially favor faster development and maturation at smaller sizes [27]. Variation in body size may be driven by a variety of mechanisms across divergent species; therefore, looking at ecogeographical patterns across species with similar physiology and behavior may be instructive for identifying the underlying causes of these patterns [28].

The problem of size variation in males and females has long been discussed in the literature. Some studies have presented higher amplitude in males size variation in geographical gradients [29]. However, particular investigations into ground beetle body size variation have not supported that opinion. On the contrary, some studies have shown that males are more variable neither in latitude nor in altitude gradients [30,31].

In our work, we hypothesized that (i) body size variation in the studied species, Pterostichus melanarius (Illiger, 1798) (Coleoptera, Carabidae), should be sawtooth because of the breeding peculiarities of that species; (ii) different traits vary differently in latitude/longitude gradients; (iii) trait variation in males should not be steeper than in females in the mentioned gradients.

\section{Materials and Methods}

\subsection{Study Organism}

Pterostichus melanarius is a very prolific and widespread European-Siberian beetle. Its southern distribution extends to northern Spain and its eastern - to the Amur River [32]. 
It was introduced in North America [33,34]. It is an eurytopic species occurring in open habitats (meadows, agricultural fields) and in all types of forests and gardens as well [35-37]. Pterostichus melanarius is a transpalearctic mesophilic zoophagous, generalist species [38-41]. It is an autumn breeder [38], with a polyvariant life cycle with multiseasonal reproduction and hibernation of larvae and adults of the first and second years of life [42,43].

Feeding resources affect the distribution of $P$. malanarius [44]. Its preferences in the selection of potential food objects have been studied: in a laboratory experiment, $P$. melanarius consumed Formicidae, Silphidae larvae, small species of Staphylinidae, Coccinellidae, Dermestidae, larvae of Lepidoptera, Hemiptera, Thomisidae, Opiliones and Lumbricidae [45,46]; this species readily feeds on other carabid species (Stomis pumicatus (Panzer, 1795), Harpalus amplicollis Mentries, 1848, Panagaeus bipustulatus (Fabricius, 1775), Leistus ferrugineus (Linnaeus, 1758), Notiophilus laticollis Chaudoir, 1850, species of Bembidion Latreille, 1802 and Amara Bonelli, 1810 genera, and other carabid's larvae). In turn, other large predators (ground beetles Carabus granulatus Linnaeus, 1758, Broscus cephalotes (Linnaeus, 1758), and staphylinids, e.g., Staphylinus caesareus Cederhjelm, 1798) prey on P. melanarius [47].

As a generalist species, P. melanarius is regarded as a good model species for the purposes of studying the morphometric variation in differing environments [48]. Its high abundance in a wide range of biotopes (including islands and flooded plots on flood-plains and urbanized cenoses) has allowed vast databases on morphometric variation in this species to be created. The latter have been used in studies of body size variation in insects along geographical gradients and also in relation to carabids' adaptation to anthropogenic impact $[49,50]$.

Climate changes affect life cycles, and the future range of P. melanarius has been modeled accordingly [51]. Modeling processes have drawn prognostic maps of the species' distribution related to climate change according to four scenarios. Mean annual temperatures and the mean temperature in the warmest and the coldest quarters of the year were the major factors affecting the spatial distribution of P. melanarius. Visualization of the potential range according to RCP 2.6, RCP 4.5, and RCP 6.0 scenarios predicted a range reduction by 2050, but its recovery by 2070 . According to the RCP 8.5 scenario, the range of the species studied will be significantly transformed: by 2070, the range will shift towards the north-west in the continental European states but to the northeast in the coastal states. By 2070, almost all southern territories of Europe will become unsuitable for P. melanarius survival. The most visible changes will be the shift in range to the north in the eastern part of the European plain. The comfort conditions for P. melanarius decrease in mountain regions, including the Alps, Carpathians, Caucasus, and Urals. By 2070, the coenotic optimum will significantly decrease on the Balkan Peninsula. Thus, a sharp reduction in Southern European and Mediterranean populations has been predicted [51].

\subsection{Sampling Area}

The sampling area included vast territory in different provinces of Russia, including Siberia, and several sites in four European countries (Table 1, Figure 1).

As seen from Table 1, the studied localities differed by 17 degrees in latitude and 121 degrees in longitude. In relation to latitude, we considered the difference sufficient according to the several papers devoted to latitude gradient investigations in different invertebrate taxa life traits [52-54]. We sampled beetles in at least three plots in every studied region. Those plots differed in some parameters: anthropogenic impact, vegetation, etc. However, we took into account that our investigation was large in scale. Due to the huge number of sampled and measured beetles, we performed the study by developing a high-throughput approach. This kind of approach has become popular in recent decades. It involves gathering data from scattered publications on the definite item, colligating it, and making conclusions on the given topic, e.g., [29]. 
Table 1. Sampling localities and sample size.

\begin{tabular}{|c|c|c|c|c|c|c|}
\hline $\mathbf{N}$ & Region & $\begin{array}{l}\text { Latitude, } \\
{ }^{\circ} \mathbf{N}\end{array}$ & $\begin{array}{c}\text { Longitude, } \\
{ }^{\circ} \mathrm{E}\end{array}$ & $\begin{array}{l}\text { Number of } \\
\text { Sites }\end{array}$ & $\begin{array}{l}\text { Type of } \\
\text { Habitats }\end{array}$ & $\begin{array}{c}\text { Sample } \\
\text { Size }\end{array}$ \\
\hline $1^{1}$ & Tatarstan Republic & $55^{\circ} 47^{\prime}$ & $49^{\circ} 06^{\prime}$ & 53 & Meadow, birch, oak, elm & 11,312 \\
\hline 2 & Sverdlovsk region & $58^{\circ} 42^{\prime}$ & $61^{\circ} 20^{\prime}$ & 6 & Meadow, pine, birch & 458 \\
\hline 3 & Kemerovo region & $54^{\circ} 56^{\prime}$ & $87^{\circ} 14^{\prime}$ & 20 & Meadows, birch, lawn & 1954 \\
\hline 5 & Udmurtia Republic & $57^{\circ} 17^{\prime}$ & $52^{\circ} 45^{\prime}$ & 16 & Birch, oak, elm & 396 \\
\hline 6 & Mariy El Republic & $56^{\circ} 42^{\prime}$ & $47^{\circ} 52^{\prime}$ & 14 & Meadow, birch, oak & 67 \\
\hline 7 & Cis-Ural & $57^{\circ} 01^{\prime}$ & $57^{\circ} 9^{\prime}$ & 21 & Birch, oak, elm & 58 \\
\hline 8 & Stavropol region & $45^{\circ} 02^{\prime}$ & $41^{\circ} 55^{\prime}$ & 6 & Meadow, birch & 76 \\
\hline 12 & Ukraine & $48^{\circ} 27^{\prime}$ & $34^{\circ} 56^{\prime}$ & & Artificial forest plantation & 225 \\
\hline 14 & Kostroma region & $57^{\circ} 48^{\prime}$ & $41^{\circ} 19^{\prime}$ & 3 & $\begin{array}{l}\text { Fir dominated ecosystem } \\
\text { recovery after felling }\end{array}$ & 60 \\
\hline 15 & Belarus & $55^{\circ} 13^{\prime}$ & $30^{\circ} 18^{\prime}$ & 3 & $\begin{array}{l}\text { Forest with pine, oak, } \\
\text { alder, willow }\end{array}$ & 369 \\
\hline 16 & Germany & $52^{\circ} 45^{\prime}$ & $9^{\circ} 23^{\prime}$ & 18 & Oilseed rape fields & 1339 \\
\hline 17 & Kaluga region & $54^{\circ} 32^{\prime}$ & $36^{\circ} 16^{\prime}$ & 8 & Gardens, old-growth forest & 233 \\
\hline 18 & Switzerland & $47^{\circ} 23^{\prime}$ & $8^{\circ} 05^{\prime}$ & 8 & Oilseed rape fields & 450 \\
\hline 19 & Kirov region & $58^{\circ} 001^{\prime}$ & $48^{\circ} 027^{\prime}$ & 3 & $\begin{array}{l}\text { Spruce, lime and oak } \\
\text { forests }\end{array}$ & 57 \\
\hline 21 & Yakutsk region & $62^{\circ} 01^{\prime}$ & $129^{\circ} 43^{\prime}$ & 2 & Meadows, lawn & 48 \\
\hline
\end{tabular}

${ }^{1}$ In the first column are the numbers that corresponded to the number in the database of our laboratory. The latter includes newly studied regions. In some regions, we did not record P. melanarius, so these regions were not included in the analysis. Therefore, the numbers in the first column are not continuous. These numbers are included in Figure 1 and are noted on the X-axis.

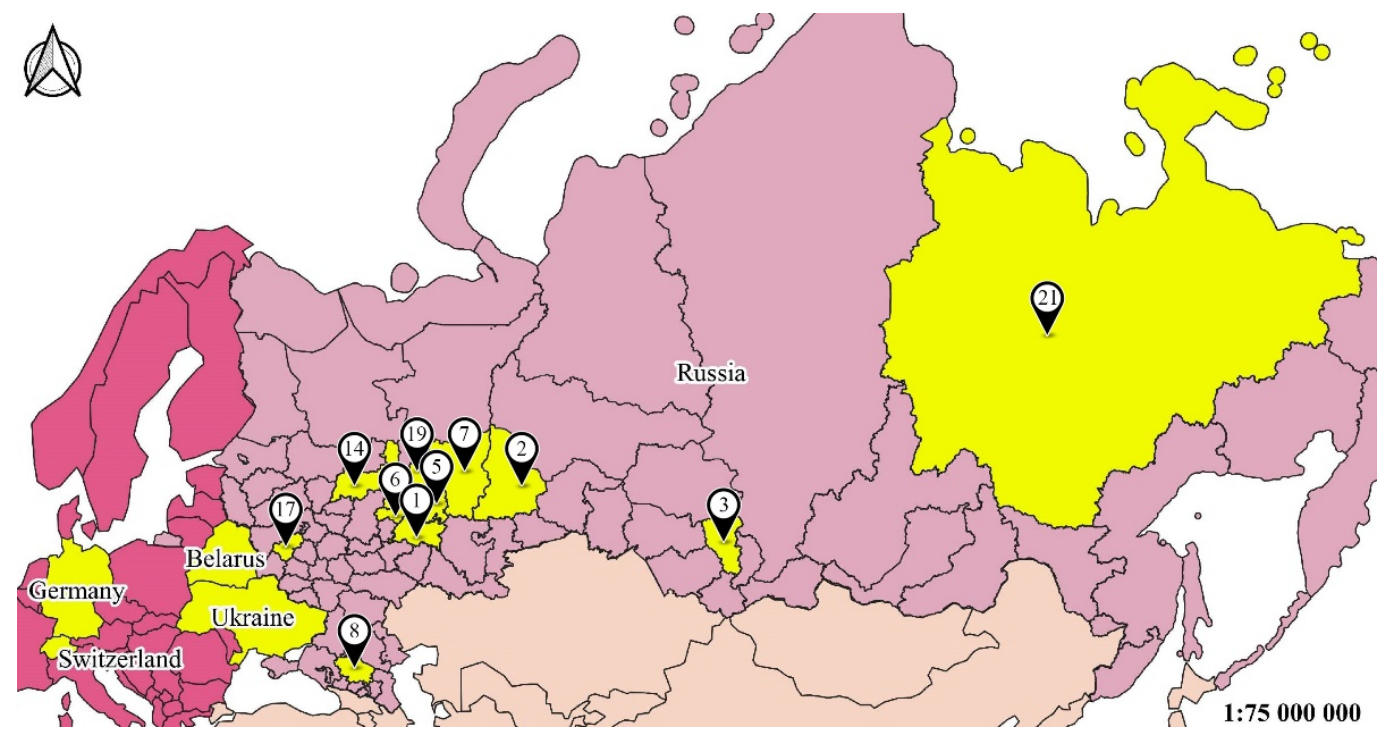

Figure 1. Map of the study. Note: Sampling localities; see Table 1.

\subsection{Study Design}

Beetles were sampled in the given regions in 2010-2018. All beetles captured in each locality during that period formed the dataset for morphometric analysis for that locality. Studied animals were captured using pitfall traps with saline solution. Each sampling plot comprised a direct line of traps with over $10 \mathrm{~m}$ distance between each. Sampling trap exposition lasted approximately 5 days. Subsequently, animals were preserved in $70 \%$ alcohol prior to taxonomic differentiation and were deposited straightened onto cotton padding thereafter.

The number of insects collected in each region was equal to the number of insects analyzed morphologically. Thus, the numbers in the last column of Table 1 are the numbers of measured beetles. 
All paddings with captured beetles were transferred to the Laboratory of Biomonitoring (The Institute of Problems in Ecology and Mineral Wealth, Tatarstan Academy of Sciences) for photographing. All photos were taken by one person using the same method. Morphometric data were collected from images taken by a Nikon D5100 camera with a custom opaque light disperser and a box with an opaque reflective surface. Measurements were taken using a program designated specifically for the given method of measurement and utilized a distance between manually pointed out elements of photo arrays as the terminal point of measurements and the fiducial scale, using the latter to bind the real scale to the array output data. Thus, the measuring was done using "Manual Carabid morphometric measurement for the method by Sukhodolskaya". Initial codes from the latter are available under the free permissive license MIT [55]. The utilized morphometric data corresponded to six linear scalar float recordings as dependent variables and were given for following values (denoting letters are given as Cyrillic transliteration of reference material's source) (Figure 2).

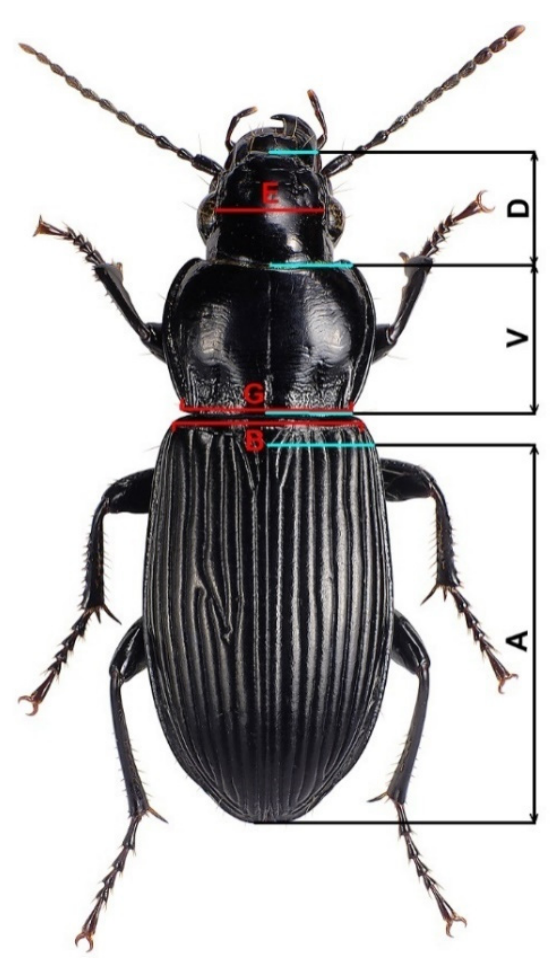

Figure 2. Placement of morphometric measurements. A-Elytra length as distance between posterior end of scutellum and terminus of right elytron (in the case of absence of intact right elytron, left one is acceptable). B-Elytra width as distance between anterior-distal corners of elytra. V-Pronotum length measured along of central furrow. G-Pronotum width as distance between posterior corners of the pronotum. D-Head length as distance between labrum and juncture of occiput and postgena. E-Head width as distance between proximal innermost sides of eyes. Measured sample size is presented in Table 1.

\subsection{Statistical Analysis}

A linear regression model was used to assess the relationship between ground beetle size and geographic coordinates:

$$
Y_{k, i}=a_{k, 0}+a_{k, 1} \cdot I_{\text {male }}\left(\operatorname{Sex}_{i}\right)+a_{k, 2} \cdot \operatorname{Coord}_{i}+a_{k, 3} \cdot I_{\text {male }}\left(\operatorname{Sex}_{i}\right) \cdot \operatorname{Coord}_{i}+\varepsilon_{k, i}
$$

where $k$ is the index of the dimension (A-Elytra Length, B-Elytra Width, V-Pronotum Length, G-Pronotum Width, D-Head Length, E-Eye Distance), $i$ is the index of the ground beetle specimen, $Y_{k, i}$ is the dimension value, $I_{\text {male }}\left(\operatorname{Sex}_{i}\right)$ is the indicator function 
that takes a value of 0 for females and 1 for males, Coord ${ }_{i}$ is the geographic coordinate (longitude or latitude), $\varepsilon_{k, i}$ is the random error, and $a_{k, 0}, a_{k, 1}, a_{k, 2}, a_{k, 3}$ are the coefficients of the model.

The $a_{k, 0}$ coefficient is the model intercept for females, the $a_{k, 1}$ coefficient is a correction to it for males, $a_{k, 2}$ is the slope of the regression for females, and $a_{k, 3}$ is an amendment to it for males, which allows us to estimate the sexual dimorphism in the dependence of size on geographic coordinates and its significance.

\section{Results}

The elytra length variation in P. melanarius by latitude gradient was sawtooth (Figure 3); trait values sharply changed between the 8 th and 16 th regions, situated within $5^{\circ}$ in latitude. A relatively smooth curve between $51^{\circ}$ and $57^{\circ}$ (the regions designated as $16,17,3,15,1,6$, 14 on the horizontal axes) gave way to a sharp rise in the trait values in the populations at the regions practically at the same latitude (regions 5, 7). Then, elytra length decreased again and sharply increased in the most northern region (21). The longitude gradient in elytra length variation was no less dramatic (Figure 4). However, the trends of trait increase were statistically significant in both gradients (Tables 2 and 3). In addition, they did not differ in males and females (Figures 5 and 6). It was common for both gradients that males were smaller than females (excluding populations of $P$. melanarius in 3 studied regions out of 15).

Sawtooth patterns were more strongly expressed in the other trait variations (Figures S1-S10): the values changed in the populations of neighboring regions in latitude gradient and the longitude as well. Regression coefficients were significant in all cases, excluding pronotum length variation in both gradients and elytra width variation in longitude (Tables S2, S6, S7). Thus, in the latitude gradient, elytra parameters increased (Figures 2 and S1, Tables 2 and S1), and pronotum length did not change but the width increased (Tables S2 and S3). Head parameters decreased (Tables S4 and S5). In the longitude gradient, the changes were as follows: elytra length increased (Table 2), but its width did not change (Table S6); pronotum length did not change, but its width increased (Tables S7 and S8); the head parameters decreased (Tables S9 and S10). Thus, we observed an elytra length increase and head parameter decrease northwards and eastwards.

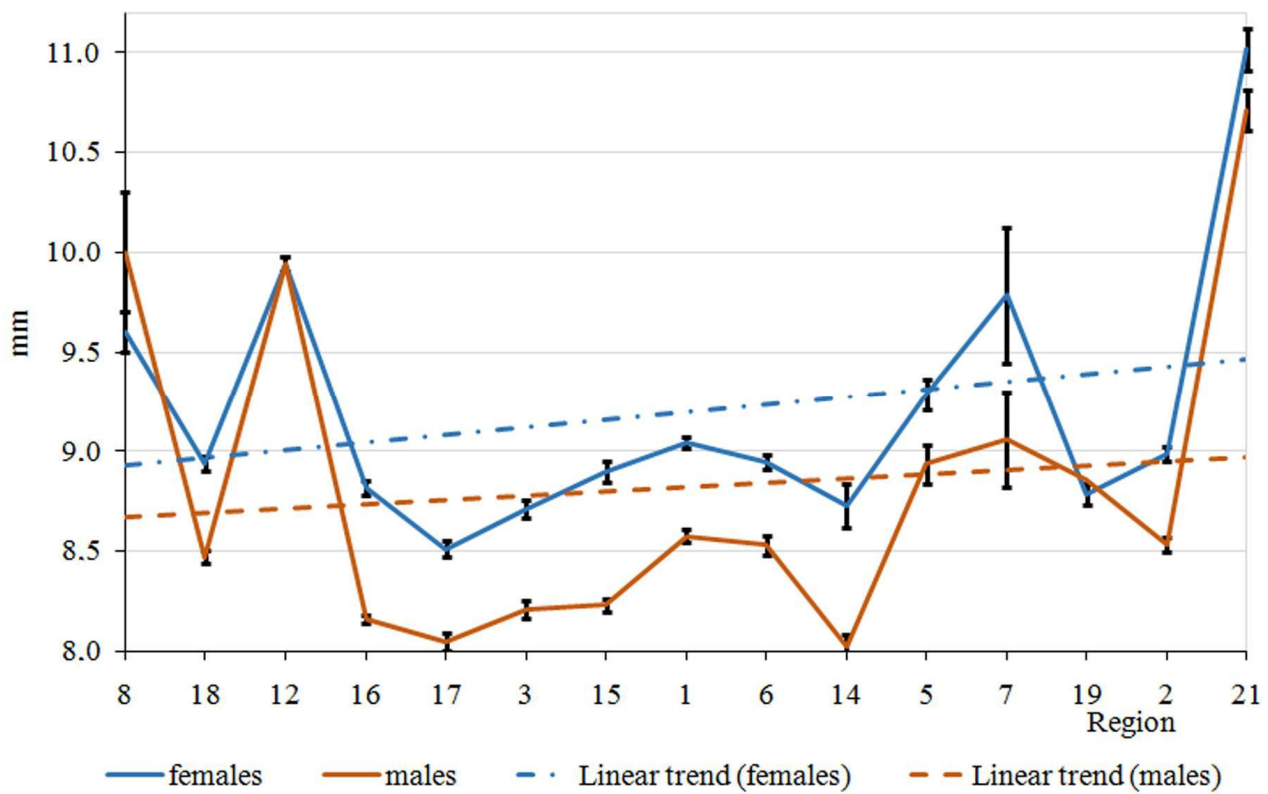

Figure 3. Elytra length variation in latitude gradient in P. melanarius. 


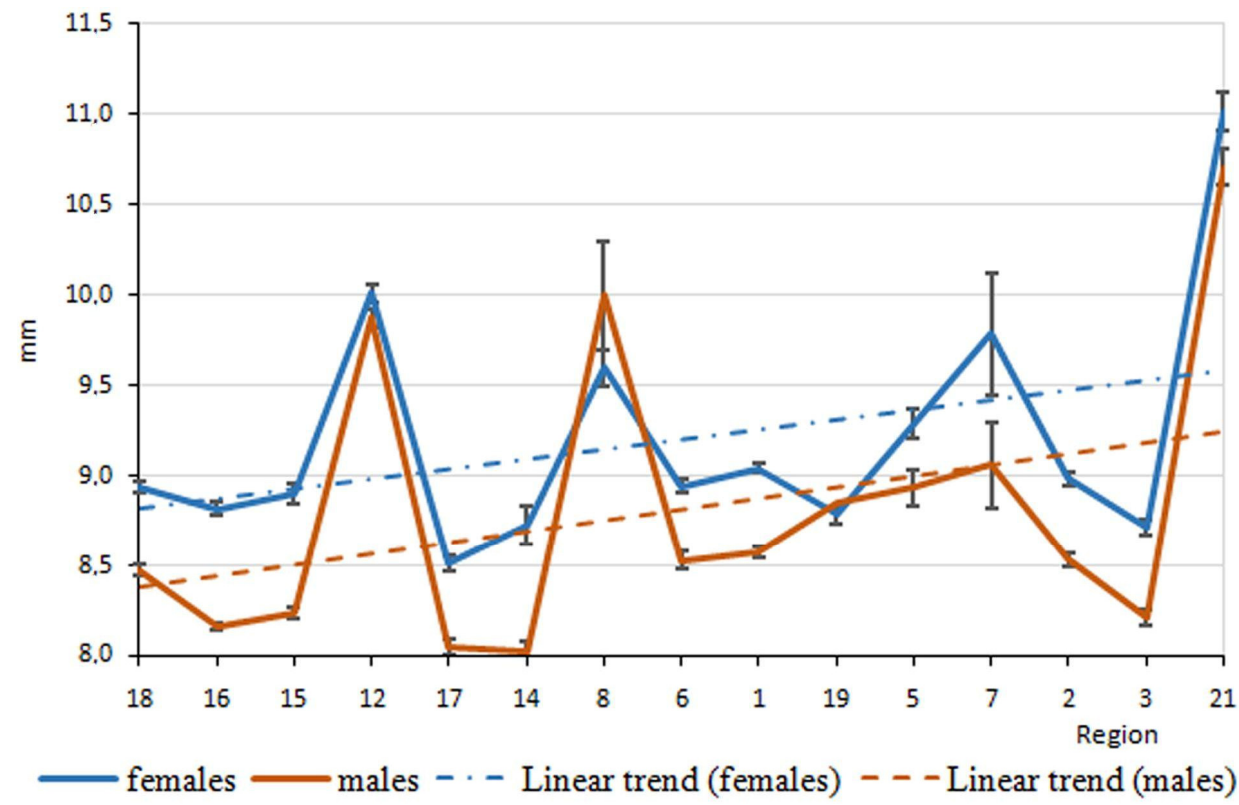

Figure 4. Elytra length variation in longitude gradient in P. melanarius.

Table 2. Regression results in latitude elytra length variation in P. melanarius.

\begin{tabular}{cccccc}
\hline & Estimate & Std. Error & t Value & $\operatorname{Pr}(>|\mathbf{t}|)$ & \\
\hline (Intercept) & 7.8008 & 0.1933 & 40.350 & $<2 \times 10^{-16}$ & $* * *$ \\
fSexMale & -0.9916 & 0.2692 & -3.683 & 0.0002 & $* * *$ \\
Lat & 0.0276 & 0.0035 & 7.869 & $4.16 \times 10^{-15}$ & $* * *$ \\
fSexMale:Lat & 0.0022 & 0.0049 & 0.447 & 0.6549 & \\
\hline
\end{tabular}

Notes. fSexMale-how males differed in trait size from females (here we see that they were smaller); Latsignificance of regression coefficient in females (latitude affected trait size in positive direction); fSexMale:Latdifference in regression coefficients between males and females (it was insignificant); ${ }^{* * *} p$-level $<0.001$.

Table 3. Regression results in longitude elytra length variation in P. melanarius.

\begin{tabular}{cccccc}
\hline & Estimate & Std. Error & t value & $\operatorname{Pr}(>|\mathbf{t}|)$ & \\
\hline (Intercept) & 9.1650 & 0.0301 & 303.632 & $<2 \times 10^{-16}$ & $* * *$ \\
fSexMale & -0.9406 & 0.0418 & -22.488 & $<2 \times 10^{-16}$ & $* * *$ \\
Lon & 0.0032 & 0.0005 & 5.561 & $2.8 \times 10^{-8}$ & $* * *$ \\
fSexMale:Lon & 0.0012 & 0.0008 & 1.564 & 0.118 & \\
\hline
\end{tabular}

Note: see Table 2. ${ }^{* * *} p$-level $<0.001$.

We mention that the trends of the latitude and longitude elytra length variation were similar in both sexes because p-levels were not significant when comparing female and male regression curves. We compared these curves in relation to the other traits studied (Figures S11-S20): p-levels were significant only in four cases-in relation to pronotum parameter variation in the latitude gradient (Figures S12 and S13) and elytra width and the pronotum length variation in the longitude gradient (Figures S16 and S17). Therefore, in general, there was no evidence for the greatest steepness in trait variation in males compared with females. 
Lat, $\mathrm{A}(\mathrm{p}$-value $=\mathbf{0 . 6 5 5})$

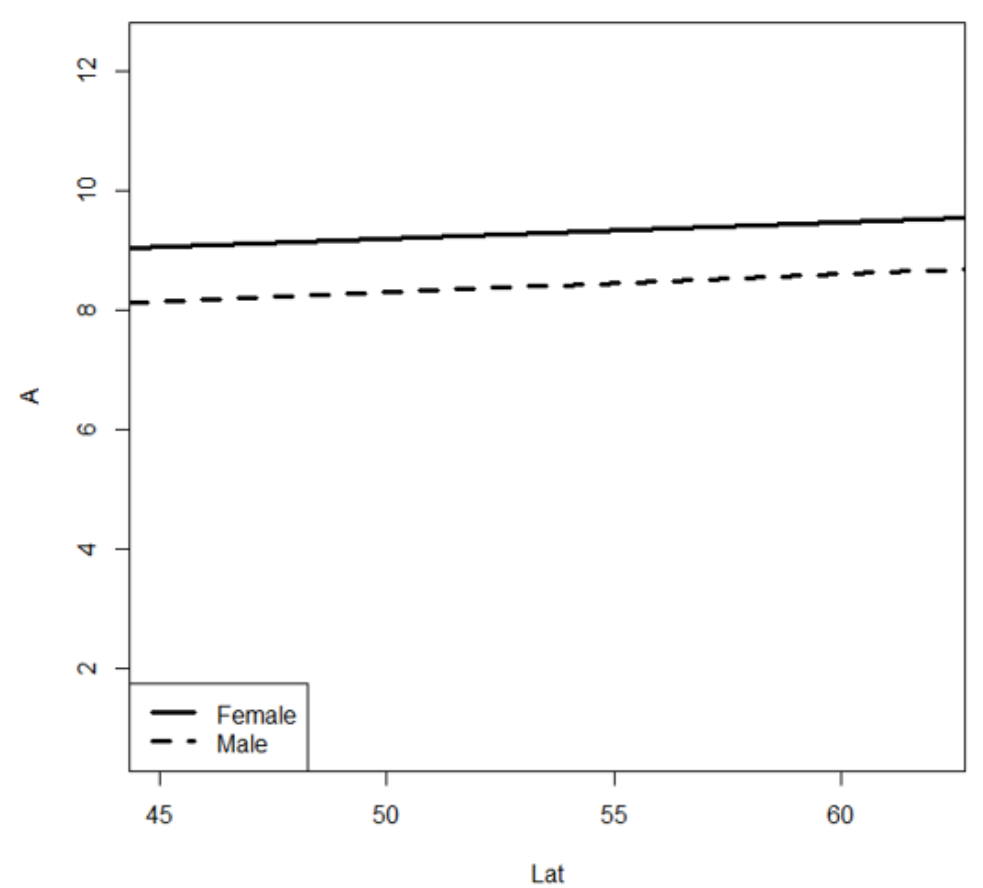

Figure 5. Regression slopes of elytra length variation in latitude gradient in P. melanarius.

Lon, $\mathrm{A}(\mathrm{p}$-value $\mathbf{= 0 . 1 1 8})$

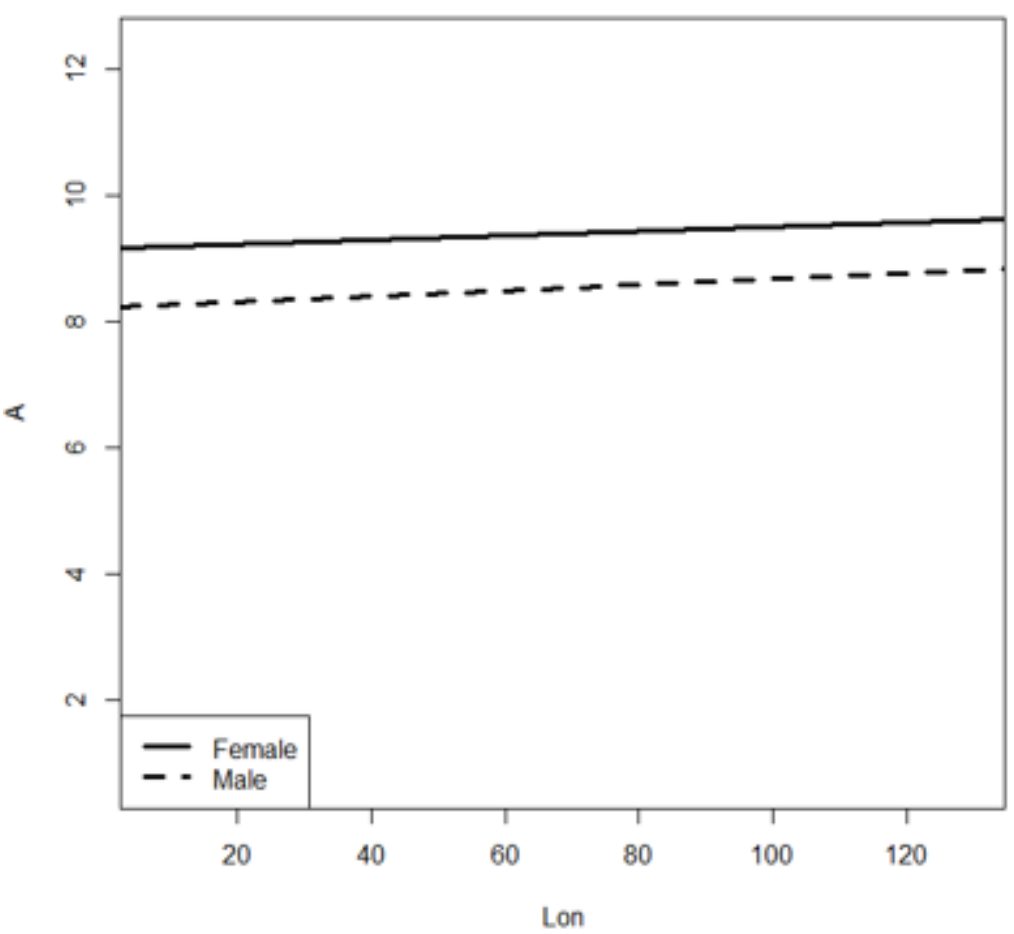

Figure 6. Regression slopes of elytra length variation in longitude gradient in P. melanarius.

\section{Discussion}

We did not find regular body size variation for P. melanarius by latitude or longitude gradients in relation to all six treated traits. Only elytra and pronotum length curves were U-shaped. Similar results were obtained in a study of damsfly body size variation, where insects were larger at the northern and southern edges of the area [56]. The authors explained 
that fact by the facilitating dispersal ability and increasing investment in reproduction via fecundity. However, they used the single parameter as the proxy of body size. In our study, elytra width increased by latitude gradient and decreased by longitude. The other traits varied in a sawtooth manner. In this case, our results are in accordance with those of researchers who investigated wasps intraspecific body size (the range in latitude was $20^{\circ}$ and in longitude $30^{\circ}$ ). It was correlated with latitude, elevation, and broad-scale climate variation. However, the direction of that relationship was idiosyncratic across species, with Bergmann's clines and converse Bergmann's clines equally represented. There was no evidence of phylogenetic signal in the direction of the cline between body size and the environment [57].

We consider that in our case the main explanatory variable for body size variation was the study region. In this relation, we agree with Nils Hein's studies of P. palustris: its body size variation showed a somehow curvilinear pattern, probably related to the transition zones between the elevational belts. In both sexes, the explanatory variables, sorted by their importance in decreasing order, were (1) study region; (2) elevation; (3) topographic position [58]. It is important to note that topographical position remained in the last position. In this view, our hypotheses is in agreement: in large-scale studies, the impact of local highly diverse factors should not be taken into account due to the fact that it would distort the general pattern. Widespread species are exposed to a variety of environmental conditions throughout their distribution range, often resulting in local adaptations [59]. Spatial variation in fitness-related traits often reflects differences in selective pressures, which determine these adaptations [60-62]. Clinal variation may indicate such local adaptation, as geographical clines are strongly related to environmental gradients, which may pose differential challenges to survival and reproduction. In addition, animals may also exhibit striking body size variation at smaller spatial scale for nearby locations with similar climate characteristics but with variation in microhabitat conditions, such as the nature of the substrate, which may impose nutritional and/or hydric constraints [63].

It is worth noting the differences in males and females in geographical body size variation. In a review based on results of a large number of publications, it was found that males' latitudinal body size clines were steeper than those of females [29]. This resulted in greater among-population variation in male than female body size, and the magnitude of the allometric slope between male and female size increased significantly with the ratio of male to female latitudinal clines in body size (but not with dimorphism). The authors focused on the relationship between dimorphism allometry and sex-specific latitudinal clines. However, a weak part of the work was that the authors used information that was not obtained independently. For many cases, it might be that the establishment of consistent genetic differences in dimorphism among populations, presumably due to sex-specific selection [64,65], is likely hampered by factors such as phenotypic plasticity [66], gene flow between populations [67], temporal variability in selection on male or female size, e.g., [68], or nonequilibrium dimorphism arising from the generally very high genetic correlation between male and female size [69]. Clines also vary over time, which is especially relevant for quickly evolving organisms such as insects. In addition, carabids' body size depends on various local factors (nutrient source, wintering conditions, soil humidity, vegetation, etc.). This is why the data set of our research included samples from several seasons in certain latitudes, different types of biotopes, and the anthropogenic impact in each province. We argue that the types of beetles' body part variation are the result of latitude impact. There are significant issues when researchers gather insect body size data not from specimen measuring but from previous literature, where body size was an ancillary data point in unrelated experiments (see Blanckenhorn et al. [29]). In our study, all measurements were performed by a single researcher staff according to a single method. We did not find that male variation in body size was steeper that female variation.

Second, another approach should be used additionally to solve the problem of similarity in body size variation in different sexes. Expanding the range of our research, we intend to follow some researchers who used neighboring latitude regions [30]. Accordingly, 
traits shifts and their significance were estimated for two neighboring regions. In addition, they could not apply the simple regression analysis in their case for the reasons that body size variation in the species studied could be sawtooth, as was shown for the ground beetle in our earlier study on Pterostichus melanarius [16].

Nevertheless, identifying the putative microevolutionary mechanisms causing geographical clines among species requires studying variation in dimorphism among populations in detail and in a greater number of species. In our case, we do not solely focus on latitude/longitude clines. Localities differ in climatic and local factors, affecting the body size of the insects. The aim of the study was to trace the steepness of trait variation between the localities studied, and the steepness was found to be equal in males and females.

\section{Conclusions}

In the face of natural and anthropogenic climate change, investigating widespread species to show local variation is important, as such species may respond differently across their distribution range to ongoing environmental changes, depending on their genetically based plasticity capacities. Overall, our study identified an interesting pattern in lifehistory strategies, with sawtooth body size variation, which was expressed equally in males and females.

Supplementary Materials: The following supporting information can be downloaded at: https: / / www.mdpi.com/article/10.3390/life12010112/s1, Figure S1: Elytra width variation in latitude gradient in P. melanarius. Figure S2: Pronotum length variation in latitude gradient in P. melanarius. Figure S3: Pronotum width variation in latitude gradient in P. melanarius. Figure S4: Head length variation in latitude gradient in P. melanarius. Figure S5: Distance between eyes variation in latitude gradient in P. melanarius. Figure S6: Elytra width variation in longitude gradient in $P$. melanarius. Figure S7: Pronotum length variation in longitude gradient in P. melanarius. Figure S8: Pronotum width variation in longitude gradient in P. melanarius. Figure S9: Head length variation in longitude gradient in P. melanarius. Figure S10: Distance between eyes variation in longitude gradient in P. melanarius. Figure S11: Regression slopes of elytra width variation in latitude gradient in $P$. melanarius. Figure S12: Regression slopes of pronotum length variation in latitude gradient in P. melanarius. Figure S13: Regression slopes of pronotum width variation in latitude gradient in P. melanarius. Figure S14: Regression slopes of head length variation in latitude gradient in $P$. melanarius. Figure S15: Regression slopes of distance between eyes variation in latitude gradient in P. melanarius. Figure S16: Regression slopes of elytra width variation in longitude gradient in P. melanarius. Figure S17: Regression slopes of pronotum length variation in longitude gradient in P. melanarius. Figure S18: Regression slopes of pronotum width variation in longitude gradient in $P$. melanarius. Figure S19: Regression slopes of head length variation in longitude gradient in $P$. melanarius. Figure S20: Regression slopes of distance between eyes variation in longitude gradient in P. melanarius. Table S1: Regression results in latitude elytra width variation in P. melanarius. Table S2: Regression results in latitude pronotum length variation in P. melanarius. Table S3: Regression results in latitude pronotum width variation in P. melanarius. Table S4: Regression results in latitude head length variation in P. melanarius. Table S5: Regression results in latitude distance between eyes variation in P. melanarius. Table S6: Regression results in longitude elytra width variation in P. melanarius. Table S7: Regression results in longitude pronotum length variation in P. melanarius. Table S8: Regression results in longitude pronotum width variation in P. melanarius. Table S9: Regression results in longitude head length variation in P. melanarius. Table S10: Regression results in longitude distance between eyes variation in P. melanarius.

Author Contributions: Conceptualization, R.S. (Rifgat Shagidullin), S.L.; validation, A.S., R.S. (Raisa Sukhodolskaya); software, A.S.; methodology, R.S. (Rifgat Shagidullin); writing-original draft preparation, R.S. (Rifgat Shagidullin), S.L.; writing—review and editing, R.S. (Rifgat Shagidullin), S.L., T.T.; visualization, V.B., S.L.; data curation, R.S. (Rifgat Shagidullin), A.S., V.B.; resources, R.S. (Rifgat Shagidullin), N.U., I.V., I.S., A.A., R.S. (Raisa Sukhodolskaya), T.T., S.N., V.B., V.A., S.L. All authors have read and agreed to the published version of the manuscript.

Funding: This research received no external funding. The material from Germany and Switzerland was collected with the financial aid and in parallel with the implementation of the Project BiodivERsA- 
FACCE2014-47 "SusTaining AgriCultural ChAnge Through ecological engineering and Optimal use of natural resources (STACCATO)".

Institutional Review Board Statement: Not applicable.

Informed Consent Statement: Not applicable.

Data Availability Statement: Not applicable.

Conflicts of Interest: The authors declare no conflict of interest.

\section{References}

1. Thompson, J.N. Relentless Evolution; The University of Chicago Press: Chicago, IL, USA, 2013; 499p.

2. Chown, S.L.; Addo-Bediako, A.; Gaston, K.J. Physiological Variation in Insects: Large-Scale Patterns and Their Implications. Comp. Biochem. Physiol. Part B Biochem. Mol. Biol. 2002, 131, 587-602. [CrossRef]

3. Chown, S.L.; Gaston, K.J. Body Size Variation in Insects: A Macroecological Perspective. Biol. Rev. 2010, 85, 139-169. [CrossRef] [PubMed]

4. Angilletta, M.J. Temperature, Growth Rate, and Body Size in Ectotherms: Fitting Pieces of a Life-History Puzzle. Integr. Comp. Biol. 2004, 44, 498-509. [CrossRef] [PubMed]

5. Høye, T.; Hammel, J. Climate Change and Altitudinal Variation in Sexual Size Dimorphism of Arctic Wolf Spiders. Clim. Res. 2010, 41, 259-265. [CrossRef]

6. Hodkinson, I.D. Terrestrial Insects along Elevation Gradients: Species and Community Responses to Altitude. Biol. Rev. 2005, 80, 489. [CrossRef]

7. Bowden, J.J.; Høye, T.T.; Buddle, C.M. Fecundity and Sexual Size Dimorphism of Wolf Spiders (Araneae: Lycosidae) along an Elevational Gradient in the Arctic. Polar Biol. 2013, 36, 831-836. [CrossRef]

8. Penell, A.; Raub, F.; Höfer, H. Estimating Biomass from Body Size of European Spiders Based on Regression Models. J. Arachnol. 2018, 46, 413. [CrossRef]

9. Smith, C.C.; Fretwell, S.D. The Optimal Balance between Size and Number of Offspring. Am. Nat. 1974, 108, 499-506. [CrossRef]

10. Fox, C.W.; Czesak, M.E. Evolutionary Ecology of Progeny Size in Arthropods. Annu. Rev. Entomol. 2000, 45, 341-369. [CrossRef]

11. Gaston, K.J.; Jackson, S.F.; Cantú-Salazar, L.; Cruz-Piñón, G. The Ecological Performance of Protected Areas. Annu. Rev. Ecol. Evol. Syst. 2008, 39, 93-113. [CrossRef]

12. Kingsolver, J.G.; Huey, R.B. Size, Temperature, and Fitness: Three Rules. Evol. Ecol. Res. 2008, 10, 251-268.

13. Koivula, M. Useful Model Organisms, Indicators, or Both? Ground Beetles (Coleoptera, Carabidae) Reflecting Environmental Conditions. ZooKeys 2011, 100, 287-317. [CrossRef]

14. Meiri, S.; Yom-Tov, Y.; Geffen, E. What Determines Conformity to Bergmann's Rule? Glob. Ecol. Biogeogr. 2007, 16, 788-794. [CrossRef]

15. Shelomi, M. Where Are We Now? Bergmann's Rule SensuLato in Insects. Am. Nat. 2012, 180, 511-519. [CrossRef]

16. Sukhodolskaya, R.; Saveliev, A. Intra-Specific Body Size Variation of Ground Beetles (Coleoptera: Carabidae) in Latitudinal Gradient. Period. Biol. 2016, 118, 273-280. [CrossRef]

17. Sukhodolskaya, R.; Saveliev, A. Impact of Environmental Factors on the Body Shape Variation and Sexual Shape Dimorphism in Carabus granulatus L. (Coleoptera: Carabidae). Zool. Syst. 2017, 42, 71-89. [CrossRef]

18. Atkinson, D. Temperature and Organism Size-A Biological Law for Ectotherms? In Advances in Ecological Research; Elsevier: Amsterdam, The Netherlands, 1994; Volume 25, pp. 1-58. [CrossRef]

19. Badejo, O.; Skaldina, O.; Sorvari, J. Spatial and Temporal Variation in Thermal Melanism in the Aposematic Common Wasp (Vespula vulgaris) in Northern Europe. Ann. Zool. Fenn. 2018, 55, 67-78. [CrossRef]

20. Polidori, C.; Gutiérrez-Cánovas, C.; Sánchez, E.; Tormos, J.; Castro, L.; Sánchez-Fernández, D. Climate Change-driven Body Size Shrinking in a Social Wasp. Ecol. Entomol. 2020, 45, 130-141. [CrossRef]

21. Dayan, T.; Simberloff, D. Size Patterns among Competitors: Ecological Character Displacement and Character Release in Mammals, with Special Reference to Island Populations. Mammal Rev. 1998, 28, 99-124. [CrossRef]

22. Watt, C.; Mitchell, S.; Salewski, V. Bergmann's Rule; a Concept Cluster? Oikos 2010, 119, 89-100. [CrossRef]

23. Roslin, T.; Hardwick, B.; Novotny, V.; Petry, W.K.; Andrew, N.R.; Asmus, A.; Barrio, I.C.; Basset, Y.; Boesing, A.L.; Bonebrake, T.C.; et al. Higher Predation Risk for Insect Prey at Low Latitudes and Elevations. Science 2017, 356, 742-744. [CrossRef]

24. Berrigan, D.; Charnov, E.L. Reaction Norms for Age and Size at Maturity in Response to Temperature: A Puzzle for Life Historians. Oikos 1994, 70, 474. [CrossRef]

25. Hoffmann, A.A.; Harshman, L.G. Desiccation and Starvation Resistance in Drosophila: Patterns of Variation at the Species, Population and Intrapopulation Levels. Heredity 1999, 83, 637-643. [CrossRef]

26. Cushman, J.H.; Lawton, J.H.; Manly, B.F.J. Latitudinal Patterns in European Ant Assemblages: Variation in Species Richness and Body Size. Oecologia 1993, 95, 30-37. [CrossRef]

27. Blanckenhorn, W.U.; Demont, M. Bergmann and Converse Bergmann Latitudinal Clines in Arthropods: Two Ends of a Continuum? Integr. Comp. Biol. 2004, 44, 413-424. [CrossRef] 
28. Angilletta, M.J., Jr.; Dunham, A.E. The Temperature-Size Rule in Ectotherms: Simple Evolutionary Explanations May Not Be General. Am. Nat. 2003, 162, 332-342. [CrossRef]

29. Blanckenhorn, W.U.; Stillwell, R.C.; Young, K.A.; Fox, C.W.; Ashton, K.G. When RenschMeets Bergmann: Does Sexual Size Dimorphism Change Systematically with Latitude? Evolution 2006, 60, 2004-2011. [CrossRef]

30. Sukhodolskaya, R.A.; Saveliev, A.A.; Ukhova, N.L.; Vorobyova, I.G.; Solodovnikov, I.A.; Anciferov, A.L.; Gordienko, T.A.; Shagidullin, R.R.; Vavilov, D.N. Modeling Sexual Differences of Body Size Variation in Ground Beetles in Geographical Gradient (The Case Study in Pterostichus oblongpunctatus Fabricius, 1787). GSC Biol. Pharm. Sci. 2020, 13, 149-161. [CrossRef]

31. Sukhodolskaya, R.; Ananina, T.; Avtaeva, T.; Saveliev, A. Sexual Size Dimorphism in Ground Beetles and its Variation in Altitude Gradient. In Advances in Medicine and Biology; Berhardt, L.V., Ed.; Nova Science Publishers: Hauppauge, NY, USA, 2021; Volume 191. [CrossRef]

32. Bousquet, Y. Tribe Pterostichini. In Catalogue of Palearctic Coleoptera. Archostemata-Myxophaga-Adephaga; Löbl, J., Smetana, A., Eds.; Apollo Books: Stenstrup, Denmark, 2003; Volume 1, pp. 462-521.

33. Niemelä, J.; Spence, J.R. Community Impacts of an Exotic Carabid: Pterostichus melanarius in Western Canadian Forests. In Carabid Beetles; Desender, K., Dufrene, M., Loreau, M., Luff, M.L., Maelfait, J.P., Eds.; Springer Nature: Basingstoke, UK, $1994 ;$ pp. 331-335.

34. Niemela, J.; Spence, J.R.; Carcamo, H. Establishment and Interactions of Carabid Populations: An Experiment with Native and Introduced Species. Ecography 1997, 20, 643-652. [CrossRef]

35. Thomas, C.F.G.; Parkinson, L.; Marshall, E.J.P. Isolating the Components of Activity-Density for the Carabid Beetle Pterostichus melanarius in Farmland. Oecologia 1998, 116, 103-112. [CrossRef] [PubMed]

36. Sukhodolskyay, R.A. Population Characteristic of Ground Beetles Dwelling the Cottages. In Animals and Plants Synantropization Pleshanov, A.S., Ed.; Institute of Geography, Siberian Branch of the Russian Academy of Science: Irkutsk, Russia, 2007; pp. 99-102.

37. Fournier, E.; Loreau, M. Activity and Satiation State in Pterostichus melanarius: An Experiment in Different Agricultural Habitats: P. melanarius Foraging Activity in Agricultural Habitats. Ecol. Entomol. 2001, 26, 235-244. [CrossRef]

38. Kryzhanovskij, O.L.; Belousov, I.A.; Kabak, I.I.; Kataev, B.M.; Makarov, K.V.; Shilenkov, V.G. A Checklist of the Ground-Beetles of Russia and Adjacent Lands (Insecta, Coleoptera, Carabidae); Pensoft-series Faunistica; Pensoft: Sofia, Bulgaria, 1995; 275p.

39. Freude, H.; Harde, K.W.; Lohse, G.A. Die Käfer Mitteleuropas. Band 2. Adephaga. 1. Carabidae (Laufkäfer); Elsevier: Berlin/Heidelberg, Germany, 2004.

40. Putchkov, A. Ground Beetles of the Ukraine (Coleoptera, Carabidae). ZooKeys 2011, 100, 503-515. [CrossRef]

41. Puchkov, A.V. Ground-Beetles (Coleoptera, Carabidae) of Transformed Cenoses of Ukraine; I.I. Schmalhausen Institute of Zoology of National Academy of Sciences of Ukraine: Kiev, Ukraine, 2018; 448p, (In Ukrainian). [CrossRef]

42. Sharova, I.C.; Denisova, M.I. Sezonnaya dinamika lesnykh populyatsiy zhuzhelits roda Pterostichus (Coleoptera, Carabidae) [Seasonal dynamics of forest populations of ground beetles of the genus Pterostichus (Coleoptera, Carabidae)]. Zool. Zhurnal 1997, $76,418-427$.

43. Matalin, A.V. Geographic Variability of the Life Cycle in Pterostichus melanarius (Coleoptera, Carabidae). Entomol. Rev. 2006, 86, 409-422. [CrossRef]

44. Kielty, J.P.; Allen-Williams, L.J.; Underwood, N. Prey Preferences of Six Species of Carabidae (Coleoptera) and One Lycosidae (Araneae) Commonly Found in UK Arable Crop Fields. J. Appl. Entomol. 1999, 123, 193-200. [CrossRef]

45. Korolev, O.V.; Brygadyrenko, V.V. Comparative Analysis of Pterostichus melanarius (Coleoptera, Carabidae) Trophic Preferences in Different Condition of Laboratory Keeping. Optim. Prot. Ecosyst. 2012, 6, 178-190.

46. Korolev, O.V.; Brygadyrenko, V.V. Trophic Relations of Pterostichus melanarius (Coleoptera, Carabidae) with Dominant Species of Invertebrates in Forest Ecosystems of Steppe Dnieper Region. Visnyk Dnipropetr. Univ. Biol. Ecol. 2012, $20,48-54$.

47. Brygadyrenko, V.V.; Korolev, O.V. Peculiarities of Trophic Spectrum of Pterostichus melanarius (Coleoptera: Carabidae) in Laboratory Conditions. Visnyk Bilocerk. Derzhavnogo Agrar. Univ. 2006, 43, 67-71.

48. Brygadyrenko, V.V.; Korolev, O.V. Morphological Polymorphism in an Urban Population of Pterostichus melanarius (Illiger, 1798) (Coleoptera, Carabidae). GRAELLSIA 2015, 71, e025. [CrossRef]

49. Sukhodolskaya, R.A. Intraspecific Body Size Variation in Ground Beetles (Coleoptera, Carabidae) in Urban-Suburban-RuralNatural Gradient. Acta Biol. Univ. Daugavp. 2013, 13, 121-128.

50. Sukhodolskaya, R. Variation in Body Size and Body Shape in Ground Beetle Pterostichus melanarius Ill. (Coleoptera, Carabidae). J. Agri-Food Appl. Sci. 2014, 2, 196-205.

51. Avtaeva, T.A.; Sukhodolskaya, R.A.; Brygadyrenko, V.V. Modeling the Bioclimatic Range of Pterostichus melanarius (Coleoptera, Carabidae) in Conditions of Global Climate Change. Biosys. Divers. 2021, 29, 140-150. [CrossRef]

52. Cooper, M. Latitudinal and Longitudinal Gradients in Old World Forest Millipedes; LAP LAMBERT Academic Publishing: Beau Bassin, Mauritius, 2021; 77p.

53. Vandewoestijne, S.; Van Dyck, H. Flight Morphology along a Latitudinal Gradient in a Butterfly: Do Geographic Clines Differ between Agricultural and Woodland Landscapes? Ecography 2011, 34, 876-886. [CrossRef]

54. Śniegula, S.; Gołąb, M.J. Test for Latitudinal Variation of Life History, Behavior and Mortality in the Strictly Univoltine Damselfly Sympecma fusca (Zygoptera: Lestidae): Latitudinal Variation of Insect Traits. Entomol. Sci. 2015, 18, 479-488. [CrossRef] 
55. Mukhametnabiev, T. Manual Carabid Morphometric Measurement for Method by Sukhodolskaya. Available online: https: // github.com/CRTmatrix/-Manual-Carabid-morphometric-measurement-for-method-by-Sukhodolskaya- (accessed on 1 December 2021).

56. Outomuro, D.; Golab, M.J.; Johansson, F.; Sniegula, S. Body and Wing Size, but Not Wing Shape, Vary along a Large-Scale Latitudinal Gradient in a Damselfly. Sci. Rep. 2021, 11, 18642. [CrossRef]

57. Miller, S.E.; Sheehan, M.J. Ecogeographical Patterns of Body Size Differ among North American Paper Wasp Species. Insect. Soc. 2021, 68, 109-122. [CrossRef]

58. Hein, N.; Pétillon, J.; Pape, R.; Feilhauer, H.; Vanselow, K.A.; Löffler, J. Broad-Scale Rather than Fine-Scale Environmental Variation Drives Body Size in a Wandering Predator (Araneae, Lycosidae). Arct. Antarct. Alp. Res. 2019, 51, 315-326. [CrossRef]

59. Günter, F.; Beaulieu, M.; Freiberg, K.F.; Welzel, I.; Toshkova, N.; Žagar, A.; Simčič, T.; Fischer1, K. Genotype-environment Interactions Rule the Response of a Widespread Butterfly to Temperature Variation. J. Evol. Biol. 2020, 33, 920-929. [CrossRef]

60. Ellers, J.; Boggs, C.L. The Evolution of Wing Color in ColiasButterflies: Heritability, Sex Linkage, and Population Divergence. Evolution 2002, 56, 836. [CrossRef]

61. Kawecki, T.J.; Ebert, D. Conceptual Issues in Local Adaptation. Ecol. Lett. 2004, 7, 1225-1241. [CrossRef]

62. Craig Stillwell, R.; Fox, C.W. Geographic Variation in Body Size, Sexual Size Dimorphism and Fitness Components of a Seed Beetle: Local Adaptation versus Phenotypic Plasticity. Oikos 2009, 118, 703-712. [CrossRef]

63. Marangoni, F.; Tejedo, M.; Cogălniceanu, D. Can Age and Growth Patterns Explain the Geographical Variation in the Body Size of Two Toad Species? An. Acad. Bras. Ciênc. 2021, 93, e20190470. [CrossRef] [PubMed]

64. Fairbairn, D.J.; Preziosi, R.F. Sexual Selection and the Evolution of Allometry for Sexual Size Dimorphism in the Water Strider, Aquarius Remigis. Am. Nat. 1994, 144, 101-118. [CrossRef]

65. Blanckenhorn, W.U. The Evolution of Body Size: What Keeps Organisms Small? Q. Rev. Biol. 2000, 75, 385-407. [CrossRef]

66. Fairbairn, D.J. Allometry for Sexual Size Dimorphism: Testing Two Hypotheses for Rensch's Rule in the Water Strider Aquarius remigis. Am. Nat. 2005, 166, S69-S84. [CrossRef]

67. Kraushaar, U.; Blanckenhorn, W.U. Population Variation in Sexual Selection and its Effect on Size Allometry in Two Dung Fly Species with Contrasting Sexual Size Dimorphism. Evolution 2002, 56, 307-321. [CrossRef]

68. Holtby, L.B.; Healey, M.C. Sex-Specific Life History Tactics and Risk-Taking in Coho Salmon. Ecology 1990, 71, 678-690. [CrossRef]

69. Lande, R. SEXUAL Dimorphism, Sexual Selection, and Adaptation in Polygenic Characters. Evolution 1980, 34, 292-305. [CrossRef] 